\title{
AKTIVITAS LARVASIDA INFUSA DAUN SELEDRI (Apium graveolens L.) TERHADAP MORTALITAS LARVA NYAMUK Aedes aegypti
}

\author{
Gita Susanti ${ }^{1}$, Oom Komalasari ${ }^{2}$, Aini Ria Rahayu ${ }^{1}$ \\ ${ }^{1}$ Program Studi S1 Farmasi STIK Siti Khadijah Palembang \\ ${ }^{2}$ Badan Penelitian dan Pengembangan Daerah Provinsi Sumatera Selatan
}

\begin{abstract}
Larvacide Activity Test of Celery Leaf Infusion Apium graveolens L. to Mortality of Aedes aegypti Mosquito Larvae. Celery leaves contain flavonoids, alkaloids, tannins, saponins, and essential oils which are useful as larvicides. This study was performed to determine the larvacidal activity of celery leaf infusion on the mortality of Aedes aegypti larvae. This study used the Randomized Post Only Control Group Design method. The larvacidal concentration of testing infusion against Aedes aegypti larvae were $5 \% \mathrm{v} / \mathrm{v}, 10 \% \mathrm{v} / \mathrm{v}$, and $15 \%$ $\mathrm{v} / \mathrm{v}$. The parameters observed were the number of larvae that died within 24 hours. The results showed that larval mortality at concentrations of $5 \%, 10 \%$, and $15 \%$ were $66.6 \%, 90 \%$, and $96 \%$, respectively. It can be concluded that a concentration of $10 \%$ celery leaf infusion already has larvicidal activity forAedes aegypti.
\end{abstract}

Keywords : Larvacide, Apium graveolens, Aedes aegypti

Abstrak: Aktivitas Larvasida Infusa Daun Seledri (Apium graveolens L.) terhadap Mortalitas Larva Nyamuk Aedes aegypti. Daun seledri mengandung senyawa flavonoid, alkaloid, tannin, saponin, dan minyak atsiri yang bermanfaat sebagai larvasida. Tujuan penelitian ini yaitu untuk mengetahui aktivitas larvasida infusa daun seledri terhadap mortalitas larva nyamuk Aedes aegypti. Rancangan penelitian ini menggunakan metode Randomized Post Only Control Group Design. Konsentrasi mortalitas infusa terhadap larva nyamuk Aedes aegypti yang digunakan yaitu $5 \% \mathrm{v} / \mathrm{v}, 10 \% \mathrm{v} / \mathrm{v}$, dan $15 \% \mathrm{v} / \mathrm{v}$. Parameter yang diamati adalah jumlah larva yang mati dalam 24 jam. Hasil penelitian didapatkan mortalitas larva pada konsentrasi $5 \%$, $10 \%$, dan $15 \%$ masing-masing sebesar $66,6 \%, 90 \%$, dan $96 \%$.Dapat disimpulkan bahwa konsentrasi infusa daun seledri $10 \%$ sudah memiliki aktivitas larvasida terhadap Aedes aegypti.

Kata Kunci: Larvasida, Apium graveolens, Aedes aegypti

\section{PENDAHULUAN}

Masalah besar yang dihadapi oleh Indonesia pada saat ini adalah banyaknya masyarakat yang menderita penyakit Demam Berdarah Dengue (DBD) atau Dengue Hemorrhagic Fever (DHF). DBD merupakan penyakit endemis di Indonesia. Di Indonesia, penyakit ini ditemukan pertama kali pada tahun 1968 di Surabaya dan Jakarta. Jumlah kasus terus meningkat, baik dalam jumlah maupun luas wilayah yang terjangkit dan secara sporadis selalu terjadi kejadian luar biasa setiap tahun (Kemenkes RI, 2010).

Kemenkes RI mencatat bahwa terdapat sebanyak 110.921 kasus DBD di Indonesia pada Januari hingga 31
Oktober 2019. Menurut Dinas Kesehatan Kota Palembang, kasus DBD mencapai angka 1.542 pada Januari hingga Maret 2020. Sementara kasus DBD sejak 1 Januari hingga 6 April 2020 mencapai 1.561 kasus. Pada wilayah Sumatera Selatan, kasus paling banyak berada di Kota Palembang dengan jumlah kasus sebanyak 316 kasus dan urutan kedua adalah Prabumulih dengan total 207 kasus. Kasus terbanyak selanjutnya adalah Kabupaten Muara Enim (157 kasus), Musi Banyuasin (151 kasus), Banyuasin (147 kasus), Kota Lubuklinggau (102 kasus), Lahat (92 kasus), dan Ogan Komering Ulu Timur (79 kasus). Kemudian Ogan Ilir (68 
kasus), Ogan Komering Ilir (65), Pagaralam (42), Musi Rawas (37 kasus), Penukal Abab Lematang Ilir (37 kasus), Muratara (24 kasus), Ogan Komering Ulu Selatan (21 kasus), Ogan Komering Ulu (4 kasus) dan Empat Lawang (4 kasus). Sementara tiga kasus meninggal berasal dari Kabupaten Banyuasin, Muratara, dan Musi Rawas. Ketiga kasus tersebut adalah anak-anak karena mereka terlambat dibawa ke rumah sakit. DBD merupakan penyakit endemis yang terjadi hampir di seluruh provinsi di Indonesia. Penyakit ini disebabkan oleh virus dengue dengan vektor penyakit nyamuk Aedes aegypti dan Aedes albopictus. Aedesaegypti adalah vektor penyebab penyakit DBD yang paling banyak ditemukan penyebab penyakit ini (Kemenkes RI, 2013).

Semakin meningkatnya kasus DBD tiap tahun di setiap daerah menyebabkan pemerintah harus mengambil kebijakan yang tepat untuk mengendalikan penyebaran penyakit tersebut. Pemutusan mata rantai penularan penyakit DBD dapat dilakukan dengan membasmi atau mengendalikan sumber penularan atau vektor, yaitu nyamuk Aedes aegypti. Prinsip dari pengendalian vektor adalah menekan populasi vektor suatu penyakit serendah mungkin sehingga penularan penyakit dapat berkurang bahkan berhenti. Pengendalian vektor dapat dilakukan dengan berbagai cara, salah satunya yaitu pengendalian kimiawi dengan menggunakan insektisida (Kemenkes RI, 2010).

Temephos merupakan salah satu bahan insektisida yang berfungsi sebagai pengendalian vektor DBD. Secara kimiawi, temephos termasuk dari golongan organofosfat atau fosfat organik. Penggunaan temephos dapat dilakukan dengan cara membubuhkan temephos dan dilarutkan dalam air. Temephosmerupakan bahan insektisida yang mampu membunuh stadium larva pada habitat aslinya (Susanti,2015). Dengan melihat manfaat tersebut, penggunaan temephos dapat memberikan dampak yang positif bagi keberhasilan dalam pencegahan penyakit DBD. Akan tetapi, terdapat dampak negatif yang diakibatkan yaitu terjadinya resistensi nyamuk Aedes aegypti terhadap insektisida tersebut. Selain itu, penggunaan insektisida kimiawi yang terus menerus dapat menyebabkan efek toksik serta meninggalkan residu sehingga dapat mengganggu kesehatan pada manusia seperti gangguan pada saluran pernafasan dan iritasi pada kulit (Melanie et al.,2018).

Banyaknya dampak negatif yang ditimbulkan akibat penggunaan insektisida kimiawi menyebabkan banyaknya pencarian alternatif pencegahan DBD yang lebih aman, misalnya dengan penggunaan insektisida hayati. Insektisida hayati yang berasal dari tumbuh-tumbuhan terbukti potensial terhadappengendalian vektor, baik baik terhadap larva maupun nyamuk dewasa. Selain itu, jenis insektisida ini juga bersifat mudah terurai (bio-degradable) di alam sehingga tidak mencemari lingkungan. Insektisida hayati relatif aman bagi alam, manusia, dan binatang ternak karena menghasilkan residu yang cepat menghilang. Daya bunuh insektisida hayati berasal dari zat toksik yang dikandungnya. Zat tersebut dapat bersifat racun kontak, racun pernafasan serta racun perut pada hewan berbadan lunak (Utomo, dkk., 2010). Salah satu tanaman yang dapat dijadikan sebagai insektisida hayati adalah seledri.

Daun seledri mudah ditemukan di Indonesia karena memiliki iklim yang sesuai untuk pertumbuhan seledri. Seledri banyak digunakan sebagai bumbu penyedap pada berbagai makanan karena memiliki aroma yang khas. Aroma yang khas pada seledri tersebut berasal dari turunan ftalid. Ftalid memiliki aktivitas sebagai insektisida. Kandungan ftalid terbanyak pada seledri adalah bagian daun yaitu sebesar 74,6-76,6\%. Sedangkan pada bagian batang terdapat ftalid sebanyak56,8-74,1\%, dan pada bagian akar sebanyak 57,7-79,7\% (Sellami, et al., 2012).Selain itu, daun seledri juga mengandung senyawa alkaloid, flavonoid, tanin, minyak atsiri, 
dansaponin yang dapat bekerja sebagai racun pada larva dan dapat berfungsi sebagai insektisida (Yongkhamcha, 2010).

Berdasarkan uraian tersebut, dilakukan penelitian untuk mengetahui aktivitas larvasida infusa daun seledri (Apium graveolensL.) terhadap mortalitas larva nyamuk Aedes aegypti.

\section{METODE}

Penelitian ini bersifat eksperimental dengan rancangan Randomized Post Only Control Group Design. Penelitian dilaksanakan dari Mei sampai dengan Juli 2020 di Laboratorium Farmakologi STIK Siti Khadijah Palembang. Skrining fitokimia terhadap infusa daun seledri dilakukan dengan metode standar dengan melakukan identifikasi terhadap flavonoid, alkaloid, tanin, saponin, terpenoid dan steroid. Penelitian menggunakan larva Aedes aegypti yang telah mencapai instar III/IV. Kelompok dibagi dalam 5 kelompok uji yang terdiri dari kontrol negatif (aquadest), kontrol positif (Temephos $10 \mathrm{mg} / 100 \mathrm{~mL}$ ), kelompok perlakuan infusa daun seledri dengan konsentrasi $5 \%, 10 \%$, dan $15 \%$.Setiap kelompok berisi 10 larva dan dilakukan sebanyak 3 kali replikasi. Aktivitas larvasida infusa daun seledri ditentukan dengan menghitung persentase jumlah larva yang mati setelah kontak dengan infusa selama 24 jam.

skrining fitokimia dapat dilihat pada Tabel 1.
Infusa daun seledri menunjukkan adanya metabolit sekunder flavonoid, alkaloid, tannin, dan saponin. Hasil

Tabel 1. Skrining Fitokimia Infusa Daun Seledri

\section{Kandungan Kimia Hasil}

Flavonoid

Alkaloid

Tanin

Saponin

Terpenoid dan Steroid

$+$

$(+)=$ Ada; $(-)=$ Tidak Ada

Hasil pengujian aktivitas larvasida infusa daun seledri menunjukkan bahwa infusa konsentrasi $5 \%, 10 \%$, dan $15 \%$ memiliki aktivitas larvasida. Hasil Pengujian aktivitas larvasida dapat dilihat pada Gambar 1. Berdasarkan perhitungan persentase, didapat bahwa semakin tinggi konsentrasi infusa, aktivitas larvasida juga semakin besar. Hasil perhitungan mortalitas larva Aedes aegyptidapat dilihat pada Tabel 2 .

Tabel 2. Mortalitas Larva Aedes aegypti setelah 24 Jam Perlakuan

\begin{tabular}{lccccc}
\hline Pengulangan & \multicolumn{5}{c}{ Jumlah Larva yang Mati pada Kelompok } \\
\cline { 2 - 6 } & 1 & 2 & 3 & 4 & 5 \\
\hline I & 0 & 10 & 7 & 9 & 10 \\
II & 0 & 10 & 7 & 8 & 10 \\
III & 0 & 10 & 6 & 10 & 9 \\
\hline Jumlah & 0 & 30 & 20 & 27 & 29 \\
\hline Rata-rata & 0 & 10 & 6.6 & 9 & 9.6 \\
\hline Persentase (\%) & $\mathbf{0}$ & $\mathbf{1 0 0}$ & $\mathbf{6 6 . 6}$ & $\mathbf{9 0}$ & $\mathbf{9 6}$ \\
\hline 1=Aquadest; 2=Temephos; & 3=Infusa & 5\%; & 4=Infusa & 10\%; & $5=15 \%$
\end{tabular}




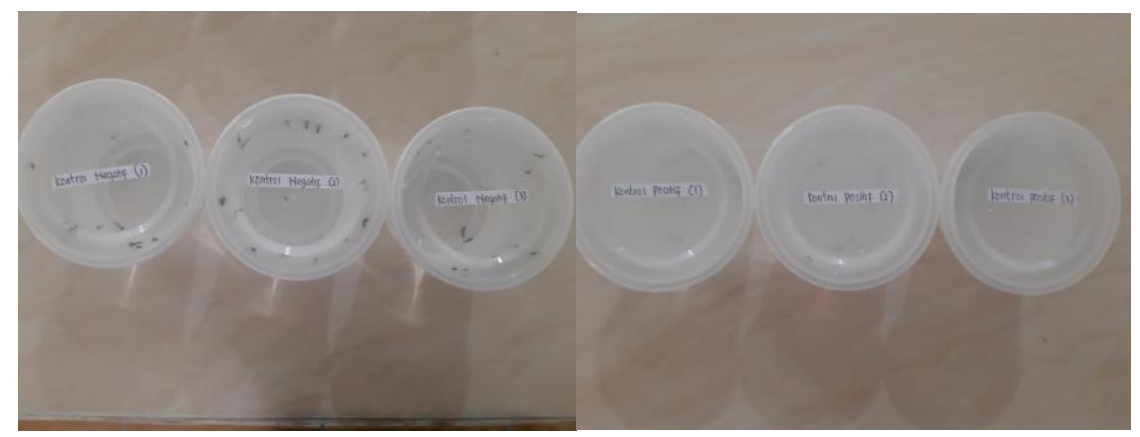

(a)

(b)

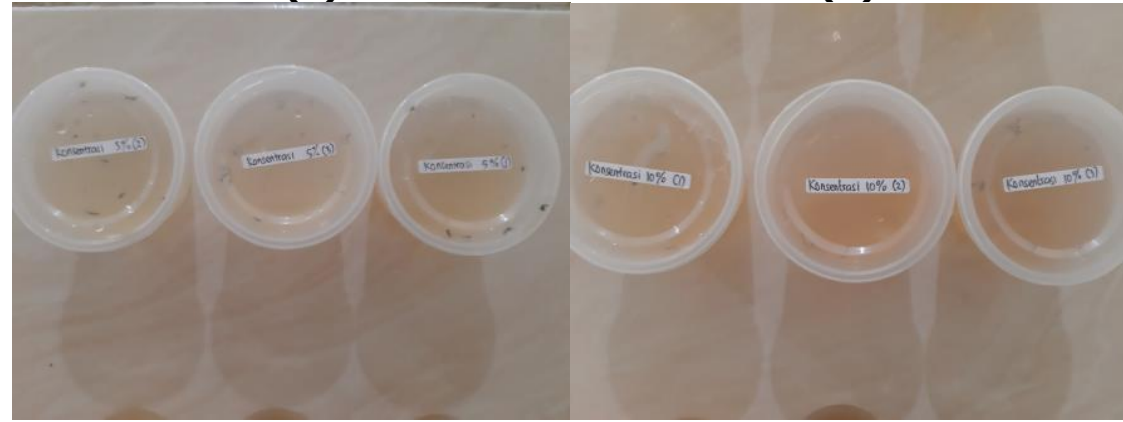

(c)ף

(d)

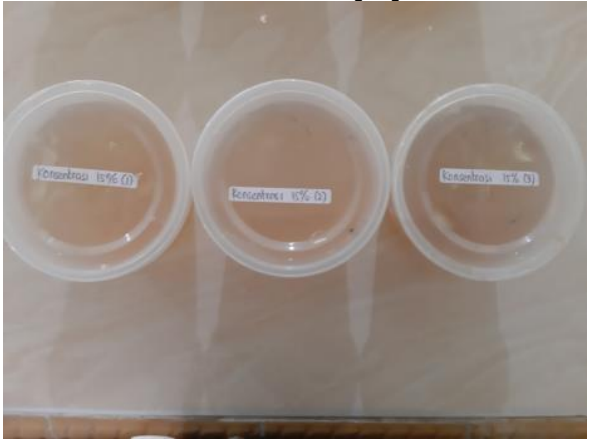

(e)

Gambar 1. Larva Aedes aegypti setelah 24 Jam Perlakuan

\section{PEMBAHASAN}

Hasil skrining fitokimia

menunjukkan bahwa senyawa yang diduga bersifat sebagai larvasida pada infusa daun seledri (Apium graveolens L.) yaitu flavonoid, alkaloid, tanin, saponin. Flavonoid yang merupakan golongan fenol dapat menyebabkan penggumpalan protein. Hal ini akan mengakibatkan transport nutrisi terganggu sehingga pertumbuhan terhambat dan akhirnya larva nyamuk akan mati. Flavonoid juga menyerang sistem saraf pada beberapa organ vital serangga sehingga menimbulkan suatu perlemahan saraf seperti pernapasan dan menyebabkan kematian (Remy dan Rexy, 2013).

Saponin dan alkaloid bertindak sebagai racun perut. Alkaloid berupa garam sehingga dapat mendegradasi membran sel untuk masuk ke dalam dan merusak sel dan juga dapat mengganggu sistem kerja syaraf larva dengan menghambat kerja enzim asetilkolinesterase. Saponin dapat menurunkan tegangan permukaan selaput mukosa traktus digestivus larva sehingga dinding traktus digestivus larva menjadi korosif. Saponin mempunyai kemampuan untuk merusak membran sel, bahan ini mirip dengan detergen, selain mengganggu lapisan lipoid dari epikutikula, saponin juga mengganggu lapisan protein endokutikula yang menyebabkan senyawa toksik dapat masuk dengan mudah ke dalam tubuh serangga atau larva (Yudha, 2013). 
Tanin akan menekan konsumsi pakan, tingkat pertumbuhan, dan kemampuan bertahan serangga menjadi lemah. Melalui mekanisme mengikat protein dalam sistem pencernaan yang diperlukan serangga untuk pertumbuhan tanin menghalangi serangga dalam mencerna makanan, sehingga proses penyerapan protein dalam sistem pencernaan menjadi terganggu (Yudha, 2013).

Dalam penelitian ini, digunakan larva Aedes aegypti instar III atau IV, karena pada stadium ini, larva membutuhkan makanan untuk berkembang sehingga infusa seledri dapat terminum oleh larva. Pada stadium pupa, sudah tidak memerlukan makanan lagi. Larva instar III atau IV ukurannya sudah cukup besar sehingga mudah untuk diidentifikasi serta merupakan sampel penelitian yang menjadi standar dari WHO. Larva instar III dan IV juga tidak cepat berubah menjadi pupa dan sudah memiliki struktur tubuh yang terbentuksempurna namun dinding tubuhnya belum mengalami pengerasan. Selainitu, dari segi teknis media yang digunakan adalah gelas yang berisi air100 mL, apabila media diisi larva nyamuk terlalu banyak, kematian larva bisa karena faktor kepadatan dalam media.

Dari hasil pengamatan terlihat pada kontrol negatif tidak ada yang mengalami kematian. Hal ini menunjukkan aquades tidak memberikan efek membunuh larva nyamuk dan suhu ruangan yang digunakan tidakmempengaruhi larva nyamuk.

Dari data memperlihatkan perbedaan jumlah mortalitas larva nyamuk Aedes aegypti disetiap kenaikan konsentrasi infusa. Hal ini menunjukkan apabila konsentrasi infusa meningkat, maka kematian larva nyamuk juga akan meningkat. Pada konsentrasi infusa daun seledri $5 \%$ dapat membunuh larva dengan persentase sebesar 66,6\%, pada konsentrasi infusa daun seledri $10 \%$ dapat membunuh larva dengan persentase sebesar $90 \%$ dan pada konsentrasi infusa daun seledri $15 \%$ dapat membunuh larva dengan persentase sebesar 96\%. Menurut WHO dalam Ningsih (2010), penggunaan larvasida dikatakan efektif apabila dapat mematikan 90-100\% larva uji. Sehingga pada penelitian ini, konsentrasi infusa $10 \%$ sudah efektif membunuh larva nyamuk Aedes aegypti.

\section{KESIMPULAN}

Berdasarkan hasil analisis data penelitian dapat disimpulkan bahwa infusa daun seledri (Apium graveolens L.) mengandung flavonoid, alkaloid, tannin, dan saponin. Infusa daun seledri memiliki aktivitas larvasida terhadap larva nyamuk Aedes aegypti. Hasil perhitungan persentase didapatkan bahwa konsentrasi infusa $10 \%$ sudah efektif membunuh larva nyamuk Aedes aegypti.

\section{SARAN}

Berdasarkan hasil penelitian yang dilakukan, maka dapat disarankan untuk dilakukan uji toksisitas terhadap infusa daun seledri (Apium graveolens L.) agar didapatkan konsentrasi infusa yang efektif dan aman.

\section{DAFTAR PUSTAKA}

Kementerian Kesehatan Republik Indonesia. (2010). Demam Berdarah Dengue. Buletin Jendela Epidemiologi Volume 2. Jakarta: Pusat Data dan Surveilans Epidemiologi.

Kementerian Kesehatan Republik Indonesia. (2013). Profil Data Kesehatan Indonesia Tahun 2012. Jakarta: Kemenkes RI.

Melanie, R., Sihotang, I. S., Kasmara, H. (2018). Effectiveness of Storage Time Formulation of Bacillus thuringiensisagainst Aedes aegypti Larvae. Jurnal Unpad.

Ningsih, T.S, (2010). Uji Kerentanan Larva Aedes sppterhadap Abate Temephos (Studi Kasus Pada Larva Aedes Spp di Daerah Endemis DBD Kelurahan Tembalang Semarang. [Skripsi]. Semarang: FKM Epidemiologi dan Penyakit Tropik UNDIP. 
Remy, E.P., Rexy, Y. (2013). Pengujian Aktivitas Larvasida dari Ekstrak Ascidian lissoclinum-patella terhadap Larva Nyamuk Aedes aegypti. Jurnal Pesisir dan Laut Tropis.

Sellami,et al. (2012). Essential Oil and Aroma Composition of Leaves, Stalks and Roots of Celery (Apium graveolens Var. Dulce) from Tunisia. Journal of Essential Oil Research.

Susanti, Dixie Tri. (2015). Jenis-Jenis Larva Nyamuk di Kelurahan Karah Berombak, Kecamatan Medan Barat, Kotamadya Medan. [Skripsi]. Medan: Universitas Sumatera Utara.

Utomo M., dkk. (2010). Pengaruh Jumlah Air yang Ditambahkan pada Kemasan Serbuk Bunga Sukun(Artocarpus communis) sebagai Pengganti Isi Ulang(Refill)
Obat Nyamuk Elektrik Terhadap Lama Waktu Efektif Daya Bunuh NyamukAnopheles aconitus Lapangan. Jurnal Kesehatan Masyarakat Indonesia.

Yongkhamcha, B. (2010). Biological Control of Dengue Fever Mosquitoes (Aedes aegypti L.) by Mintweed (Hyptis suaveolens (L.) Poit), Yam Bean (Pachyrhizus erosus L.), and Celery (Apium graveolens L.) Seed Extracts. Thailand:Suranaree University of Technology.

Yudha, Wisnu, H. (2013). Efektivitas ekstrak buah bintaro (Cerbera odollam) sebagai larvasida lalat rumah (Musca domestica). [Skripsi]. Bogor: Fakultas Kedokteran Hewan, Institut Pertanian Bogor. 